\title{
Ground support: a mine manager's perspective
}

\author{
F Mercier-Langevin Agnico Eagle Mines Ltd., Canada
}

\begin{abstract}
As near-surface, easy-to-access mineral reserves progressively get depleted and become harder to replace, underground mines are pushed to greater depths and/or greater productivity to meet the increasing demand for raw materials. Nevertheless, despite increasingly challenging conditions, it can be argued that underground mining has never been safer than it is today. Part of this success can be attributed to advances in ground control practices.

This paper provides a view on how ground support integrates into the modern mining business model, from the perspective of a former rock mechanics specialist now holding a management position. Furthermore, it provides the ground control specialist with strategies to optimise communication with management.
\end{abstract}

Keywords: ground support, risk management

\section{Introduction}

Over the last 15 years, the author was very fortunate to have the opportunity to work in three of Agnico Eagle's operations in the Abitibi region of Northwestern Quebec, LaRonde, Lapa and Goldex. Despite being physically relatively close to each other, the three mines and the geotechnical challenges they face are very diverse.

Agnico Eagle is a senior Canadian gold mining company that has been producing precious metals since 1957. Its mines are located in Canada, Finland and Mexico, with exploration activities in each of these countries, as well as in the United States of America and Sweden. In 2018, it produced over 1.6 M ounces of gold (Figure 1). About half of the production in 2018 came from the Abitibi operations.

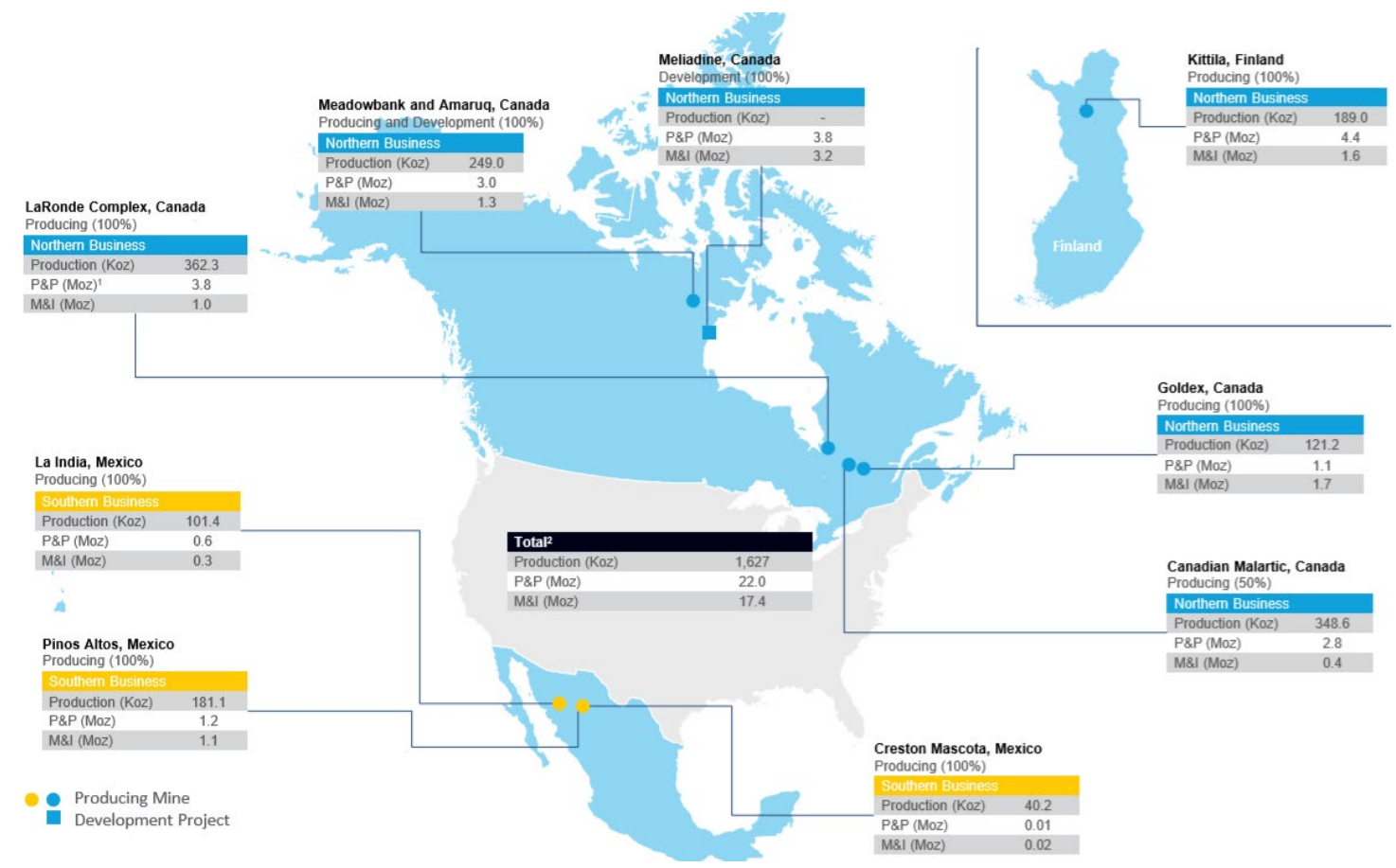

Figure 1 Agnico Eagle operations in the world. Production is for fiscal year 2018. Mineral reserves and mineral resources as of 31 December 312018 (Agnico Eagle Mines Ltd. 2019a) 


\subsection{LaRonde: deepest mine in the Americas}

Agnico Eagle's flagship LaRonde mine has been in operation since 1988. The LaRonde orebody is a world-class $\mathrm{Au}-\mathrm{Ag}-\mathrm{Cu}-\mathrm{Zn}-\mathrm{Pb}$ massive sulphide lenses complex that extends from near-surface to a depth in excess of $3,000 \mathrm{~m}$. Operations started at Shaft \#1, which serviced the relatively shallow Dumagami orebody $(1,200 \mathrm{~m}$ depth). In the late 1990s, operations transitioned to the deeper Zone 20 orebody, with a short production window from the very shallow $(550 \mathrm{~m})$ Shaft \#2. Since the early $2000 \mathrm{~s}$, Zone 20 has been providing almost all of the production via Shaft \#3 (the Penna Shaft), which is the deepest single-lift shaft in the western hemisphere at 2,250 m. As exploration continued to confirm the presence of Zone 20 at even greater depths, mining operations progressively got deeper, to the point where the construction of a winze became necessary. Shaft \#4, extending from 2,000 to $2,860 \mathrm{~m}$, was commissioned in 2009 . Today, production extends as deep as $3,110 \mathrm{~m}$ via ramp access.

Since the early days of mining, the regional foliation of the host rock encasing the orebodies resulted in squeezing ground conditions in drifts oriented subparallel to the rock fabric. As operations got progressively deeper, the resulting drift convergence was exacerbated by the increasing stresses. Mercier-Langevin \& Turcotte (2006) reported that every haulage drift below 1,940 m showed signs of squeezing, with certain areas exhibiting as much as $1 \mathrm{~m}$ of total wall closure. When squeezing became too pronounced, resulting in insufficient clearance for equipment, it was often required to 'purge' (scaling of the wall by mucking equipment), and reinstall ground support.

Various ore access strategies were implemented over the years to mitigate geotechnical risk at LaRonde (Mercier-Langevin \& Turcotte 2006; Mercier-Langevin 2008; Mercier-Langevin 2011). Geotechnical considerations for deep mine design were also presented by Mercier-Langevin (2011).

Over the years, various support system designs and strategies were tried at the mine in order to deal with squeezing ground, with varying degrees of success, until the introduction of the 'hybrid bolt', a new type of bolt developed by the mine personnel (Mercier-Langevin \& Turcotte 2007). This new bolt reduced considerably the need for costly and time-consuming purging and subsequent rehabilitation (Turcotte, 2010). Furthermore, the Hard Rock Squeezing Index was developed by Mercier-Langevin \& Hadjigeorgiou (2011), based on case studies reported from several mining operations and calibrated on in situ observations from LaRonde. This index employs the spacing of foliation planes, the stress to strength ratio of the host rock and the orientation of the tunnel with regards to foliation to estimate the squeezing potential of excavations at the mine.

Mine-induced seismicity is another challenge that LaRonde had to deal with for years. The first rockburst occurred in 2002 at a depth of approximately 1,500 m. Following this event, dynamic support was adopted in the bolting standards at the mine. The first dynamic bolting standard at LaRonde employed modified cone bolts (MCBs) in conjunction with zero gauge mesh straps. A few years after their introduction, the MCBs were found to be unsuitable in LaRonde's ground conditions (Simser et al. 2006). Fortunately, by then the hybrid bolt had shown good potential as a dynamic support (Turcotte 2010), and replaced the MCB in the dynamic bolting standard.

Since the introduction of a mine-wide seismic system in 2003 , seismic data have been employed along with field observations in order to develop site-specific strategies to address seismic risk as it evolved at the mine. The resulting mitigation measures have been refined on a continuous basis in order to minimise workforce exposure to seismic risk. Eventually, these considerations have been formalised in an auditable seismic risk management plan (Mercier-Langevin \& Hudyma 2007).

In recent years, with the bulk of mining activities transitioning to the deeper part of the orebody (below $2.4 \mathrm{~km}$ ), seismicity has taken precedence over squeezing ground as the major geotechnical challenge at LaRonde. Improved rock mass quality and higher stresses have contributed to increased levels of seismicity, both in terms of frequency and in terms of magnitude (Turcotte 2014). The mine has continued to build on its experience by using data from past seismicity to produce a site-specific version of the excavation vulnerability potential equation (or EVP) developed by Heal et al. (2006). This practical tool is used by the ground control group at the mine to evaluate and reduce seismic risk of underground excavations (Turcotte 2014). 


\subsection{Lapa: some of the most aggressive squeezing ground in mining}

The Lapa gold mine was in operation from 2009 to 2018. Even though the mine operated at relatively shallow depths (from 500 to $1,400 \mathrm{~m}$ ), the extremely weak, highly foliated and altered ultramafics resulted in very challenging ground conditions in ore drifts and haulage drifts developed at a shallow angle to foliation. These drifts exhibited some of the most extreme squeezing ground conditions observed in hard rock mining worldwide (Figure 2). Soon after operations began and squeezing ground issues became difficult to manage, the hybrid bolt was imported from LaRonde, and it proved very effective at dealing with Lapa's ground conditions as well (Turcotte 2010). The failure mechanism at play in squeezing ground at Lapa, and the employed support strategy to mitigate its effects, have been described in detail by Mercier-Langevin \& Wilson (2013).

Experience at Lapa demonstrated that the Hard Rock Squeezing Ground Index, initially developed at LaRonde, could be used successfully elsewhere. Understanding of the driving factors behind squeezing was subsequently refined through numerical modelling and further calibration by Hadjigeorgiou et al. (2013) and Karampinos et al. $(2014,2015)$. Wilson \& Mercier-Langevin (2013) documented how the low quality of the ultramafics at Lapa influenced blasting practices and dilution at the mine.
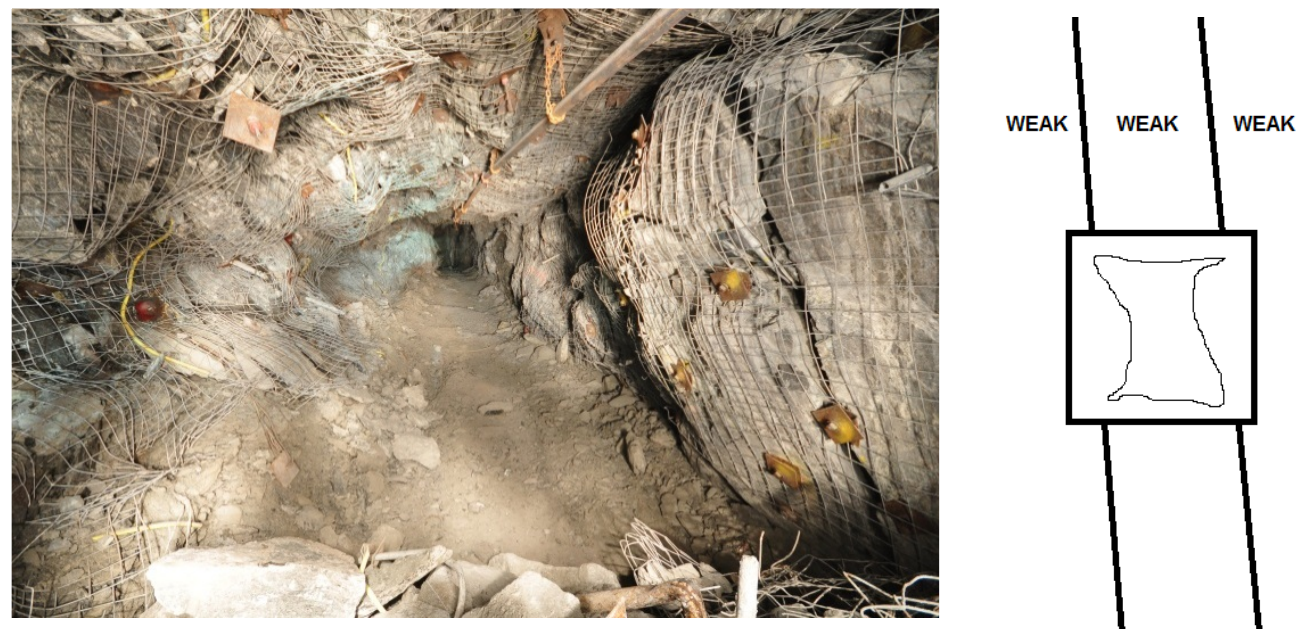

Figure 2 Late stage deformation in an ore drift entirely in ultramafics at Lapa (Mercier-Langevin \& Wilson 2013)

\subsection{Goldex: a story of resiliency}

The Goldex property was staked in the 1930s and several exploration phases have occurred since the 1960s. Early exploration phases were unsuccessful because of the low grade and high nugget effect, which resulted in lower metallurgical recoveries than expected. Starting from the second half of the 1990s, the economic and technical viability of various mining methods were examined, until a positive feasibility study was published in 2005 on the Goldex Extension Zone (GEZ). This study used a novel, high productivity and low cost mining method described by Frenette (2010) as longhole shrinkage. This novel method used concepts from other mining methods, such as:

- The high efficiency haulage level of a block cave operation.

- Wall stability of a shrinkage stoping method.

- Fragmentation of a longhole stoping method.

- Large blast and mucking flexibility of a vertical crater retreat (VCR) method.

Production from the $25 \mathrm{Mt}$ (grading $2.05 \mathrm{~g} / \mathrm{t}$ ) GEZ started in 2008, with extraction operations from the two primary stopes progressing as expected for the first two years (Hudyma et al. 2010). Unfortunately, in 2011, production from the mine had to be suspended when it appeared that a weak volcanic rock unit in the 
hanging wall of the Goldex deposit had failed. This rock failure was thought to extend between the top of the deposit and surface. As a result, this structure had allowed groundwater to flow into the mine. The additional water inflow had likely contributed to further weakening and movement of the rock mass. Considering the safety of the company's employees, and the integrity of the mine's infrastructure and that of the surrounding area, management made the decision to stop production indefinitely. Consequently, Agnico Eagle wrote off its investment in Goldex (Agnico Eagle Mines Ltd. 2011).

Nevertheless, as there was significant remaining geological potential on the property, the team at site put together a mining plan (using conventional mining methods) for the satellite zones on the property. In July 2012, mining of the $M$ and $E$ satellite zones was approved by Agnico Eagle's Board of Directors (Agnico Eagle Mines Ltd 2012).

As a prerequisite to restart operations at Goldex, a number of conditions had to be met to ensure that an event such as the one that happened in 2011 could not reoccur. This included proper understanding of the underlying causes of the 2011 event, its evolution in time and its repercussions both underground and at surface. The mine achieved commercial production again in October 2013 (Agnico Eagle Mines Ltd 2014).

Since that time, the mine has been successful at adding mineral reserves and maximising the potential of satellite orebodies. The original $\mathrm{M}$ and $\mathrm{E}$ project was based on $6.5 \mathrm{Mt}$ of ore grading $1.54 \mathrm{~g} / \mathrm{t}$ with operations until Q1 of 2017. At the end of 2018, nearly twice that amount (12.7 Mt grading $1.57 \mathrm{~g} / \mathrm{t}$ ) has been produced, with close to $18.9 \mathrm{Mt}$ grading $1.58 \mathrm{~g} / \mathrm{t}$ remaining in mineral reserves, (Agnico Eagle Mines Ltd. 2019b). Goldex mine life currently extends to 2027.

Today, as a result of the 2011 event, in excess of one thousand instruments (piezometers, optic fibres, rock pins, survey monuments, monitoring holes, extensometers, contractometers, crackmeters, flowmeters, accelerometers and geophones) are installed in and around the mine, to monitor in real time ground consolidation and settlement, watertable drawdown, rock movement, water inflow into the mine, surface infrastructure movement, microseismicity, shaft stability and potential impact on public infrastructure in and around the mine property. Data collected via this extensive network of instruments is processed and cross-referenced, and the findings reported to local management and Agnico Eagle's head office through a series of dashboards and reports. Thorough risk analyses are conducted every time that a change to the mine plan may have an impact on the consequences of the 2011 event. External audits are regularly carried out to ensure that proper perspective is maintained in the interpretation of the data. This disciplined approach ensures that due diligence is maintained at all times. Every technical and production decision at Goldex since 2011 has been taken using this framework.

\section{A mine manager's perspective}

After close to 20 years in various roles, starting as a master's student in rock mechanics (orepass stability) to the first professional role as rock mechanics engineer at LaRonde (deep mining, squeezing ground, seismicity), transitioning to chief engineer at Lapa (squeezing ground, weak rock) and now as mine manager at Goldex (convoluted geomechanical history), the author's perspective on ground support has evolved significantly over time.

\subsection{Ground support is a risk control measure}

Geomechanical risk is one of the multitude of risks that a mine manager has to take into account as part of their duties. The direct consequences of failing to properly manage this risk can range from minor (production delays) to catastrophic (fatalities). However, in today's interconnected global economy, indirect, but no less significant consequences, have to be taken into account as well. Damage to the corporation's reputation, loss of community support and loss of political support are such potential consequences of failing to manage geomechanical risk properly. One of the ways geomechanical risk can be mitigated is through the use of ground support. 
Controlling exposure to occupational hazards is viewed as the fundamental method of protecting workers. The National Institute for Occupational Safety and Health (NIOSH) provides a very useful tool to establish a hierarchy of controls as a means of determining how effective control solutions are likely to be (Figure 3 ).

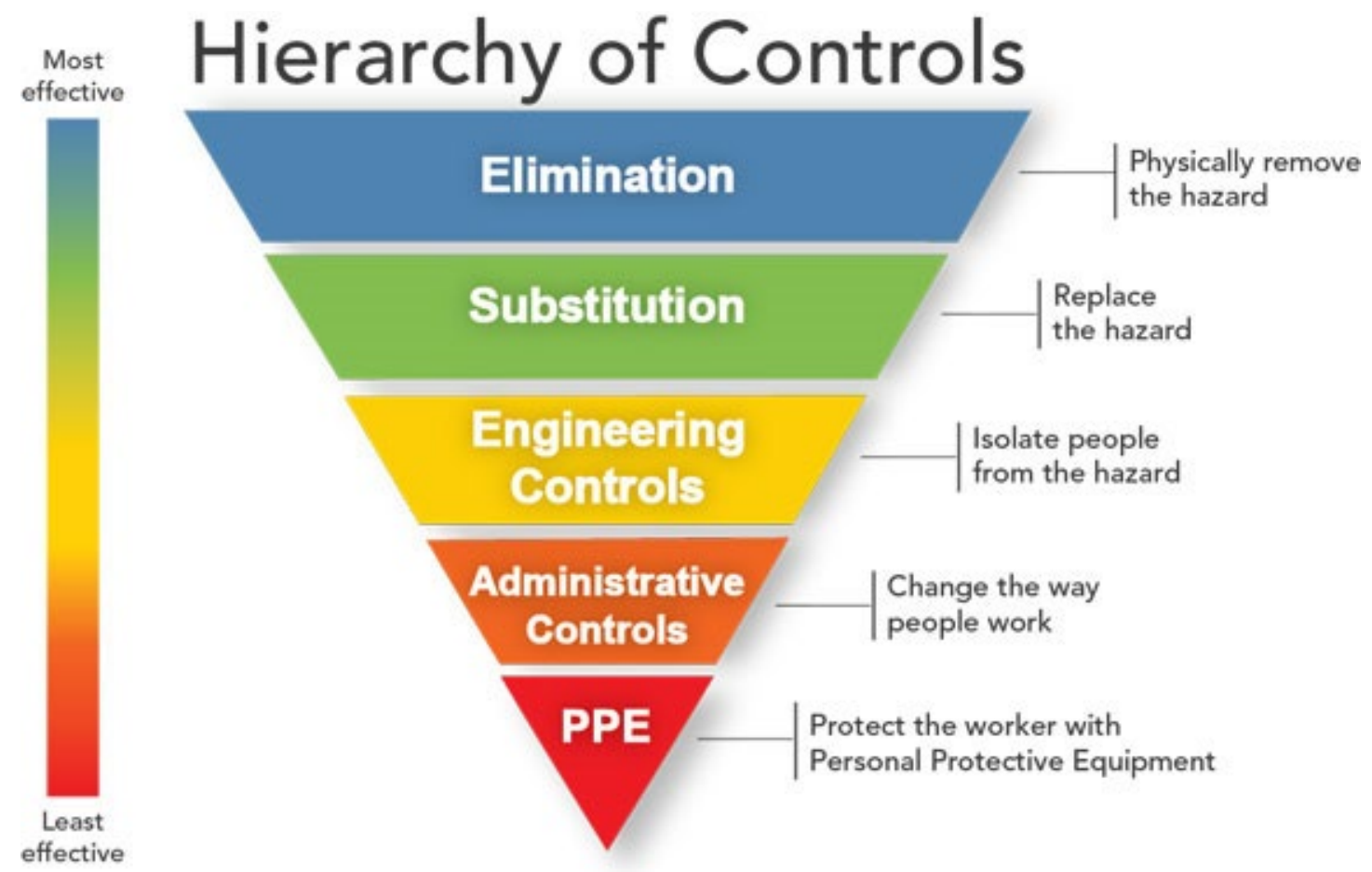

Figure 3 Hierarchy of Controls (National Institute for Occupational Safety and Health 2019)

According to NIOSH, elimination and substitution are the most effective means of reducing hazards. However, they also tend to be the most difficult to implement in an existing process.

Engineering controls are favoured over administrative controls and personal protective equipment (PPE) for controlling worker exposure in the workplace because they are designed to physically separate the worker from the hazard. Well-designed engineering controls can be highly effective in protecting workers. The initial cost of engineering controls can be higher than the cost of administrative controls or PPE, but over the long-term operating costs are frequently lower, and in some instances, can provide cost savings in other areas.

Administrative controls aim to modify human behaviour by documenting, formalising and communicating ways in which personnel can avoid risks that are present in the environment. A typical example of an administrative control is a work procedure. PPE, on the other hand, are the very last line of defence. They are worn by personnel to literally shield them against hazards to which they are directly exposed. Administrative controls and PPE programmes may be relatively inexpensive to establish but, over the long-term, can be very costly to sustain. These methods for protecting workers have also proven to be less effective than other measures, requiring significant effort by the affected workers and management alike.

The risks controlled by ground support in mines is the risk of uncontrolled falls of ground driven either by gravity or by seismicity (rockbursts). The consequences of failing to mitigate this risk can vary depending on circumstances. For example, in areas accessible to personnel, the consequence of an uncontrolled fall of ground can be in the health and safety category (injury of personnel) and/or in the economic category (temporary or permanent loss of access to mineral reserves).

Through this lens, ground support cannot be viewed as either elimination or substitution, as it in no way removes or replaces the hazard (falling/ejected rock) from the workplace. Ground support isolates people from the hazard, and as such, it can be considered as an engineering control. It should be noted that according to $\mathrm{NIOSH}$, administrative controls and PPE are frequently used with existing processes where 
hazards are not particularly well controlled. Administrative controls such as re-entry protocols after blasting to limit the exposure of workers to seismic risk are used to control this same hazard (falling/ejected rock). Similarly, PPE, such as hard hats, remains mandatory in just about any mining jurisdiction in the world. We must come to the conclusions that ground support is an engineering control, and that it is not a particularly effective one.

\subsection{Ground support is an expense}

Most of the training involved in a management position revolves around business acumen to get a better understanding of how a company makes money and to make good decisions around the money-making process. According to Cope (2012), there are five drivers that determine the success of a business (Figure 4). One of the fundamental aspects of this process upon which ground support has a direct impact is profit.

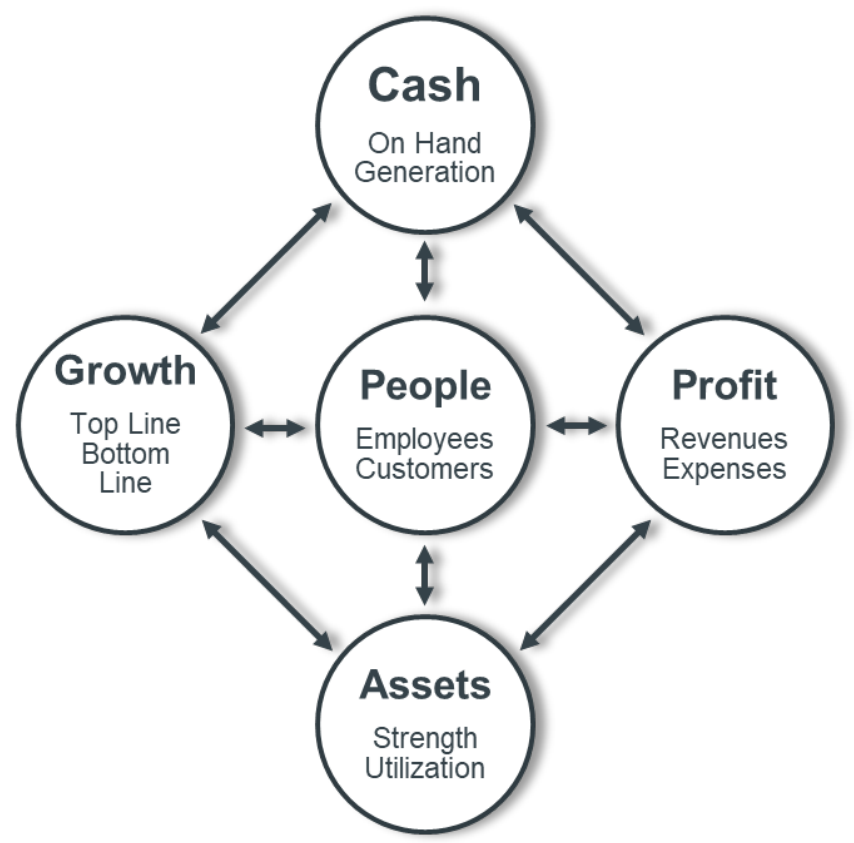

Figure 4 The five business drivers (Cope 2012)

Ground support in a mine, depending on the prevailing ground conditions, can make up a sizeable portion of its operating budget. It is beyond the scope of this paper to provide a comprehensive analysis of the costs involved in ground support, which needs to factor in the cost of labour, equipment costs (including maintenance), supervision costs, drilling consumables, energy, etc. However, simply looking at the unit cost of material involved in ground support can provide a useful indication of how much of an impact it can have on a mine's budget.

Goldex and LaRonde both rely primarily on mesh and bolts for ground support, but they have to do so in very different ground conditions. In the case of Goldex, which has comparatively better ground conditions and only nascent seismic risk at relatively shallow depths, ground support material costs are in the order of CAD 340/eq.m. (4.5 $\times 4.8 \mathrm{~m}$ equivalent, including rehabilitation). In LaRonde's much more challenging environment, with severe squeezing ground and significant seismic risk, ground support material costs are in the order of CAD 925/eq.m., almost triple that of Goldex.

In general, as ground support requirements increase, the associated time to perform the task of supporting the ground increases as well. At first, this increase is linear. But the reality of most underground mines is that operations are constrained by blasting operations. This means that ultimately, when bolting time reaches a critical level where it becomes impossible to perform the entire development cycle (muck/support/ drill/blast) in a given period (shift or day), shift change inefficiencies start to take a heavy toll on development performances. Cost per metre is directly impacted, and ultimately the mine's bottom line as well. 
A more insidious consequence of increased ground support requirements is that underground mining projects typically have long lead-times, in most instances directly tied to development performance. For marginal projects, the proper ground support design can mean the difference between being profitable or not.

\section{$3 \quad$ Striking the right balance}

With such impact on a mine's economics, it is paramount for management to be able to strike the right balance between ground support choice and costs. In this regard, the ground control specialist can play a significant role. This section presents some insights to aid a ground control specialist to become a valued ally for the mine manager in properly managing geotechnical risk.

\subsection{Ground support is complex}

The first thing to recognise as a ground control specialist is that ground support is very complex and there is a definite need for the specialist to adapt their communication style when engaging people in management positions without the same level of knowledge in this particular field. As was discussed in the introduction of this paper, ground conditions in mines even relatively close to each other, can vary significantly. This is compounded by the sheer diversity of ground support products. Ground support elements can act as surface support (mesh, shotcrete, thin spray-on liners, etc.) or act as rock reinforcement (bolts). They can also be active (such as pre-tensioned elements) or passive (such as friction bolts). They can be stiff (resin- or cement-grouted rebar) or yielding (de-bonded cable bolts). When assembled into systems, ground support elements can perform in static loading conditions or in dynamic loading conditions. They can be installed in two or more phases (primary/secondary). Finally, they can be designed to be permanent or temporary. Adding to this complexity, different suppliers also often offer very similar products with only subtle differences in design or capacity (Figure 5).

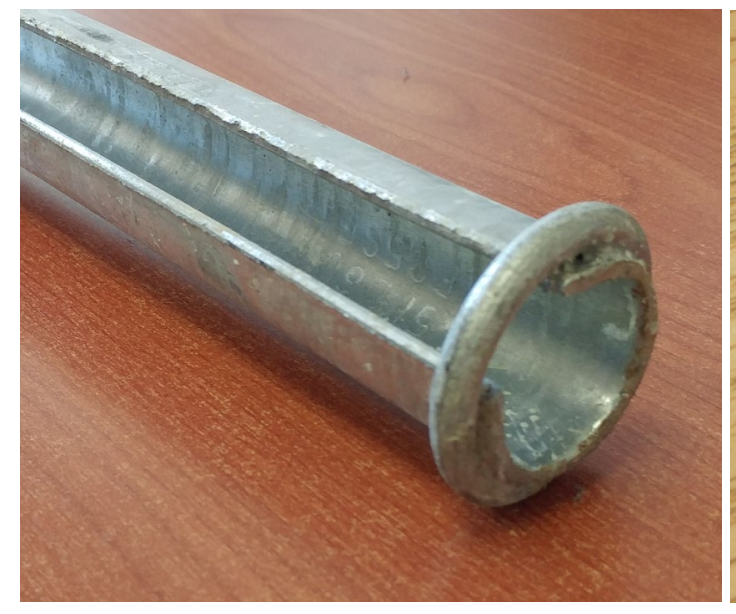

(a)

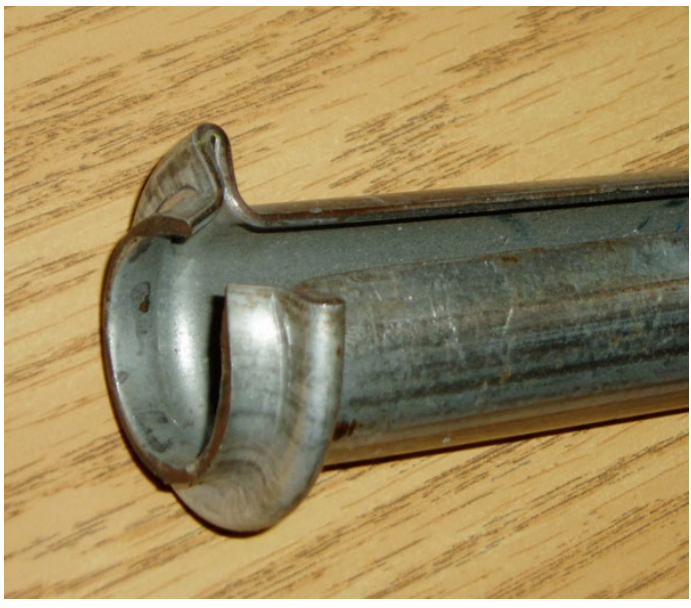

(b)

Figure 5 Friction bolts distributed by two different suppliers. Two similar products with similar functions, but slightly different head design. (a) Welded ring versus (b) Machine-pressed

Furthermore, ground support practices, like many other aspects of mining, are subject to cultural differences as well. Scandinavian and Australian mines show a high reliance on shotcrete, whereas mesh seems to be the preferred surface support in Canadian mines (Potvin \& Hadjigeorgiou 2008). Similarly, friction bolts such as the Split Set are routinely used for roof support in Australian mines with success, a practice almost nonexistent in Canadian mines. This is yet another variable that management has to take into account in its assessment of ground support practices.

All of these factors combine to form an almost endless number of possible combinations of support elements to form support systems. No convenient 'one size fits all' support design exists. 


\subsection{The paradox of prevention}

Another key element to keep in mind for the ground control specialist is that ground support suffers from the paradox of prevention, whereby success is very hard to measure as it creates non-events. What has not happened is not quantifiable, as opposed to what has happened. This makes it very difficult for a mine manager to be able to differentiate between a design that is just right and one that is overly conservative. Indeed, an excavation designed with an effective Factor of Safety (FoS) of 1.00000001 can look exactly the same as one designed with a FoS of 4 . In theory, the excavation will remain stable under both ground support strategies. However, the difference between the two designs is very apparent on the bottom line.

For dynamic conditions, this appreciation of success is made even more complicated by the fact that ground support may very well be designed to fail after a certain period of time or after a specific event. In squeezing ground, the objective of ground support is to manage deformations and keep the excavation safe for workers for its service life (Mercier-Langevin \& Hadjigeorgiou 2011). In seismically active ground, the objective of support is to withstand the amount of energy that an event of a given magnitude is expected to generate to contain rock ejection. This event is inferred from a combination of statistical analysis of available data, interpretation of future seismic risk and experience. There always remain a non-zero chance that a given seismic event could exceed the support system's capacity.

\subsection{Quality assurance and quality control processes as due diligence tools}

Most ground support systems are only as good as the quality of installation of their constituent components (Simser et al. 2006). It follows that quality assurance and quality control (QA/QC) processes are needed to ensure that ground support performs as expected and reliably so.

Most legislations today require that mines perform a certain level of QA/QC on installation of ground support. Quality assurance is process oriented and focuses on defect prevention (i.e. bolting standards, ground support elements installation procedures and storage guidelines, etc.), while quality control is product oriented and focuses on defect identification (i.e. installation audits, pull tests, etc.). A properly designed QA/QC programme for ground support should cover every aspect in its lifecycle, starting with procurement and storage requirements.

Operator and supervisor training, and subsequent conformity audits are also very important aspects of QA/QC that management should make sure are enforced adequately. Audits can be active (observation of ground support installation) or passive (inspection of a drift where ground support was installed). While both types complement each other, one should always be mindful of the 'observer effect' that is particularly felt in the first form; observation of a phenomenon inevitably changes that phenomenon. Management and the ground control specialist alike should then use a healthy dose of skepticism when periodically reviewing results of these audits.

\subsection{Communication: keep it simple}

Bolting standards are arguably the most important communication tool that ground control personnel use to establish the requirements for ground support. Most mines use multiple standards, modulated by certain factors such as the various ground conditions encountered, the size of excavation or even the orientation of the excavation relative to the rock fabric (Figure 6). While a certain flexibility in standards can be warranted for some conditions, an effort should be made to try and limit to a manageable number the number of different standards in use at the mine. Too many standards can introduce an extra level of complexity that might not be worth it; the increased demand on training required and the added potential for error in interpretation or execution that are introduced might offset the gains in theoretical performance. 


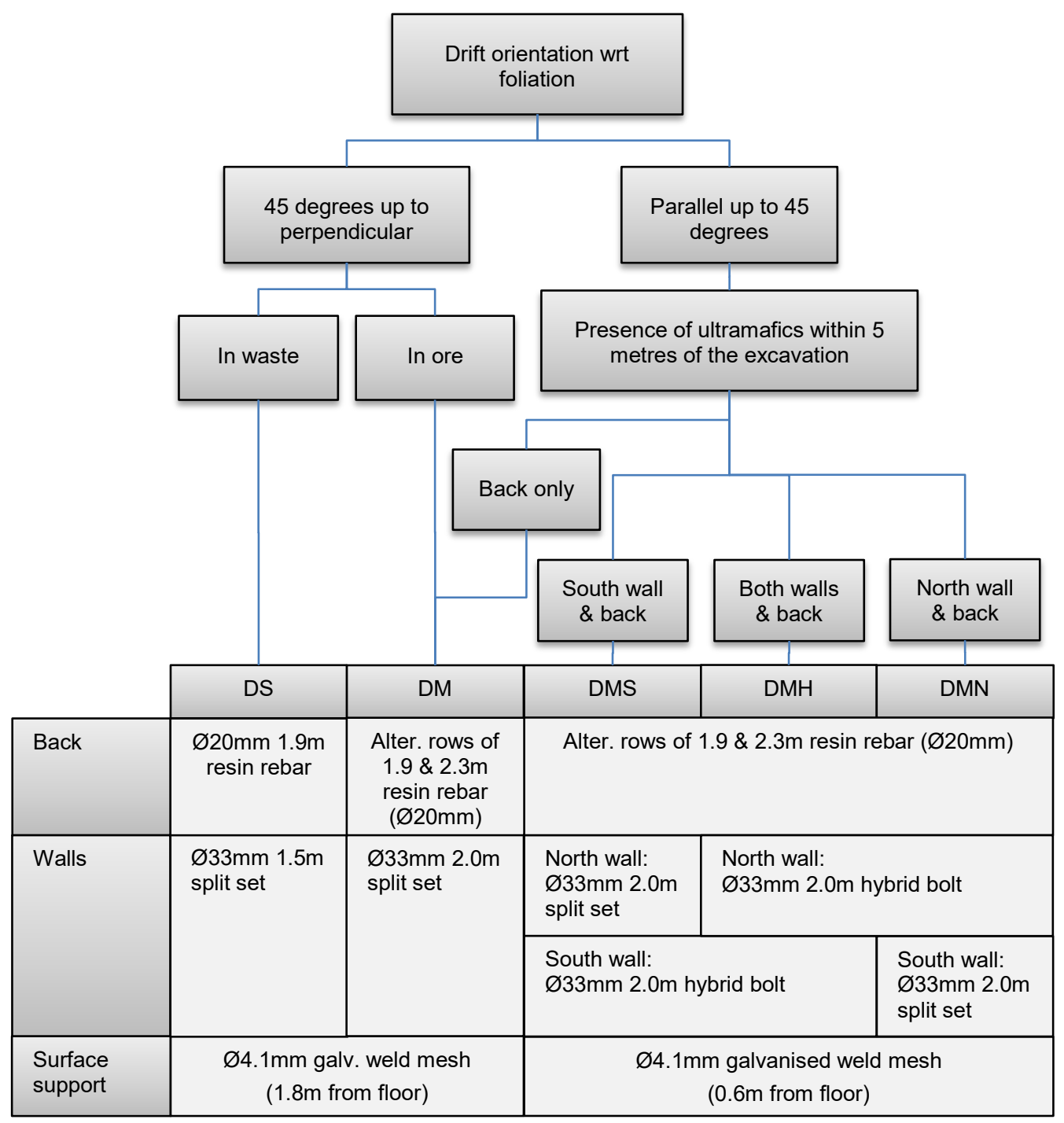

Figure 6 Ground support standard selection process used at Lapa in 2013 (Mercier-Langevin \& Wilson 2013)

\subsection{Ground support and people}

One more important aspect for ground control specialists to factor into their decisions is the fact that ground support is installed by people. In most mines, development crews have the highest paying jobs. The specific task of ground support installation falls into that category. In jurisdictions that use incentive pay systems, ground support tasks often are the ones that benefit from the highest bonus rates. They are some of the most qualified miners, often very high in the progression tree, part of the 'elite' of the mine in some respects. For most people less familiar with the mining industry, the image itself of the miner is often associated with ground support installation.

Therefore, there is a certain standing to the job, with the resulting high influence on morale of the whole operation. This fact might not be viewed as technically relevant to the design and implementation of ground support by most, but it is a critical aspect of change management. Therefore, a mine manager cannot afford to lose sight of this fact when making decisions that might affect development crews' performance. 


\section{$4 \quad$ Successful communication between the ground control specialist and the mine manager}

Hadjigeorgiou (2019) illustrated that the management of geomechanical risk is hindered by the asymmetry of knowledge at the various decision levels. Indeed, the ground control specialist has to be acutely aware that for any person in a management role without specific experience in ground control or rock mechanics, it can be a daunting task to try to understand this highly specialised field. This is made even more complicated by the paradox of prevention. Most mining companies have adopted risk registers to standardise risk monitoring, prioritisation and mitigation. Using these can potentially result in more efficient and simpler communication.

The ground control specialist should always keep in mind that ground support, as an engineering control (and not a particularly effective one), is relatively low on NIOSH's hierarchy of controls. Therefore, before introducing changes to bolting standards in response to evolving ground conditions, the first priority should be to evaluate the feasibility of revisiting the design that led to the problematic situation. Introducing changes to the design to eliminate the risk or substitute it for a more benign one, if feasible, could prove to be more effective and more profitable over the longer term and therefore should be explored first.

Demonstrating that the impact on the bottom line (both direct and indirect) of the change is understood will also reassure management that the financial impact of the change has been considered. Ideally, trade-off studies (including impact on development cycle) should be prepared and presented. Similarly, anticipating how that change will be perceived by the workforce will be seen positively.

Finally, QA/QC programmes should be a priority for the ground control specialist, as they are a demonstration of due diligence for them, their operation and their organisation.

\section{Conclusion}

It has been established that ground support is necessary to control geomechanical risk, but that there is a direct and significant cost to it. A mine manager therefore has to be able to strike the right balance between the capacity of ground support to manage geotechnical risk and its cost. In this regard, the ground control specialist can help steer more efficiently the operation on its journey towards zero harm and do it cost-effectively.

\section{Acknowledgement}

The author thanks Agnico Eagle Mines Limited for permission to publish.

\section{Note to readers}

This paper uses the term 'mineral resources' and 'mineral reserves'. For a detailed discussion on these terms please refer to:

https://agnicoeagle.com/English/operations-and-development-projects/reserves-and-resources/default.aspx

\section{References}

Agnico Eagle Mines Ltd. 2011, Agnico-Eagle's Goldex Mine to Suspend Production During Investigation and Remediation of Water Inflow and Ground Stability Issue; Book Value of Goldex to be Written Off, Agnico Eagle Mines Ltd., Toronto, viewed 14 June 2019, https://ir.agnicoeagle.com/English/investor-relations/news-and-events/news-releases/news-release-details/2011/ Agnico-Eagles-Goldex-mine-to-suspend-production-during-investigation-and-remediation-of-water-inflow-and-groundstability-issue-book-value-of-Goldex-to-be-written-off/default.aspx

Agnico Eagle Mines Ltd. 2012, Agnico-Eagle Reports Solid Second Quarter 2012 Operating and Financial Results; Increases Full Year Production Guidance; Announces Development of Satellite Zones at Goldex; Meliadine Continues To Grow, Agnico Eagle Mines Ltd., Toronto, viewed 14 June 2019, https://www.agnicoeagle.com/English/investor-relations/news-and-events/newsreleases/news-release-details/2012/Agnico-Eagle-Reports-Solid-Second-Quarter-2012-Operating-and-Financial-Results- 
Increases-Full-Year-Production-Guidance-Announces-Development-of-Satellite-Zones-at-Goldex-Meliadine-Continues-ToGrow/default.aspx

Agnico Eagle Mines Ltd. 2014, Agnico Eagle Reports Fourth Quarter and Full Year 2013 Results - Strong Operational Performance Yields Record Annual Production, Agnico Eagle Mines Ltd., Toronto, viewed 14 June 2019, https://www.agnicoeagle.com/English/investor-relations/news-and-events/news-releases/news-release-details/2014/ Agnico-Eagle-reports-fourth-quarter-and-full-year-2013-results---Strong-operational-performance-yields-record-annualproduction/default.aspx

Agnico Eagle Mines Ltd. 2019a, Operations \& Development Projects, Agnico Eagle Mines Ltd., Toronto, viewed 16 June 2019 , https://www.agnicoeagle.com/English/operations-and-development-projects/default.aspx

Agnico Eagle Mines Ltd. 2019b, Agnico Eagle Reports Fourth Quarter and Full Year 2018 Results - Three-Year Guidance Outlines Growing Production with Stable to Declining Unit Costs; Meliadine Mill Commissioning Underway with Project Ahead of Schedule and Under Budget; Year-Over-Year Increase in Mineral Reserves and Mineral Resources; Quarterly Dividend Increased, Agnico Eagle Mines Ltd., Toronto, viewed 14 June 2019, https://www.agnicoeagle.com/English/investorrelations/news-and-events/news-releases/news-release-details/2019/Agnico-Eagle-Reports-Fourth-Quarter-and-Full-Year2018-Results/default.aspx

Cope, K 2012, Seeing the Big Picture: Business Acumen to Build Your Credibility, Career, and Company, Greenleaf Book Group Press, Austin, $176 \mathrm{p}$.

Frenette, P 2010, 'The Goldex Mine mining method', in Y Potvin (ed.), Proceedings of the Second International Symposium on Block and Sublevel Caving, Australian Centre for Geomechanics, Perth, pp. 253-266.

Hadjigeorgiou, J, Karampinos, E, Turcotte, P \& Mercier-Langevin, F 2013, 'Assessment of the influence of drift orientation on observed levels of squeezing in hard rock mines', in Y Potvin \& B Brady (eds), Proceedings of the Seventh International Symposium on Ground Support in Mining and Underground Construction, Australian Centre for Geomechanics, Perth, pp. 109-117.

Hadjigeorgiou, J 2019, 'Understanding, managing and communicating geomechanical mining risk', in J Wesseloo (ed.), Proceedings of the First International Conference on Mining Geomechanical Risk, Australian Centre for Geomechanics, Perth, pp. 3-20.

Heal, DP, Potvin, Y \& Hudyma, MR 2006, 'Evaluating rockburst damage potential in underground mining', in DP Yale (ed.), Proceedings of the 41st US Symposium on Rock Mechanics, American Rock Mechanics Association, Alexandria.

Hudyma, MR, Frenette, P \& Leslie, I 2010, 'Monitoring open stope caving at Goldex Mine', in Y Potvin (ed.), Proceedings of the Second International Symposium on Block and Sublevel Caving, Australian Centre for Geomechanics, Perth, pp. 133-144.

Karampinos, E, Hadjigeorgiou, J, Turcotte, P, Drolet, M-M \& Mercier-Langevin, F 2014, 'Empirical and numerical investigation on the behaviour of foliated rock masses under high stress conditions', in M Hudyma \& Y Potvin (eds), Proceedings of the Seventh International Conference on Deep and High Stress Mining, Australian Centre for Geomechanics, Perth, pp. 345-361.

Karampinos, E, Hadjigeorgiou, J, Turcotte, P \& Mercier-Langevin, F 2015, 'Large-scale deformation in underground hard-rock mines', Journal of The Southern African Institute of Mining and Metallurgy, vol. 115, no. 7, pp. 645-652.

Mercier-Langevin, F \& Turcotte, P 2006, 'Expansion at depth at Agnico-Eagle's LaRonde Division - meeting geotechnical challenges without compromising production objectives', in Y Potvin, J Hadjigeorgiou \& D Stacey (eds), Proceedings of the Third International Seminar on Deep \& High Stress Mining, Australian Centre for Geomechanics, Perth, pp. 189-195.

Mercier-Langevin, F \& Turcotte, P 2007, 'Evolution of ground support practices at Agnico-Eagle's LaRonde Division - innovative solutions to high-stress yielding ground', in E Eberhardt, D Stead \& T Morrison (eds), Rock Mechanics: Meeting Society's Challenges \& Demands, Proceedings of the 1st Canada-US Rock Mechanics Symposium, CRC Press, Boca Raton, pp. 1497-1504.

Mercier-Langevin, F \& Hudyma, MR 2007, 'The development and implementation of a comprehensive seismic risk management plan at Agnico-Eagle's LaRonde Mine', in Y Potvin (ed.), Proceedings of the Fourth International Seminar on Deep and High Stress Mining, Australian Centre for Geomechanics, Perth, pp. 221-232.

Mercier-Langevin, F 2008, 'Stope performance under post-peak conditions', in J Hadjigeorgiou (ed.), Proceedings of the Third International Seminar on Strategic vs Tactical Approaches in Mining, Laval University, Quebec City.

Mercier-Langevin, F 2011, 'LaRonde Extension - mine design at three kilometres', Transactions of the Institution of Mining and Metallurgy, Section A, Mining Technology, vol. 120, no. 2, pp. 95-104.

Mercier-Langevin, F \& Hadjigeorgiou, J 2011, 'Towards a better understanding of squeezing potential in hard rock mines', Mining Technology Journal, vol. 120, no. 1, pp. 36-44.

Mercier-Langevin, F \& Wilson, D 2013, 'Lapa Mine - ground control practices in extreme squeezing ground', in Y Potvin \& B Brady (eds), Proceedings of the Seventh International Symposium on Ground Support in Mining and Underground Construction, Australian Centre for Geomechanics, Perth, pp. 119-131.

Potvin, Y \& Hadjigeorgiou, J, 2008, 'Ground support strategies to control large deformations in mining excavations', Journal of the Southern African Institute of Mining and Metallurgy, vol. 108, no. 7, pp. 397-404.

Simser, B, Andrieux, P, Langevin, F, Parrott, T \& Turcotte, P 2006, 'Field behaviour and failure modes of modified conebolts at the Craig, LaRonde and Brunswick Mines in Canada', in Y Potvin, J Hadjigeorgiou \& D Stacey (eds), Proceedings of the Third International Seminar on Deep \& High Stress Mining, Australian Centre for Geomechanics, Perth.

The National Institute for Occupational Safety and Health (NIOSH) 2019, Hierarchy of Controls, NIOSH, Washington, viewed 1 April 2019, https://www.cdc.gov/niosh/topics/hierarchy/default.html

Turcotte, P 2010, 'Field behaviour of hybrid bolt at LaRonde Mine', in M Van Sint Jan \& Y Potvin (eds), Proceedings of the Fifth International Seminar on Deep and High Stress Mining, Australian Centre for Geomechanics, Perth, pp. 309-319. 
Turcotte, P 2014, 'Practical applications of a rockburst database to ground support design at LaRonde Mine', in MR Hudyma \& Y Potvin (eds), Proceedings of the Seventh International Conference on Deep and High Stress Mining, Australian Centre for Geomechanics, Perth, pp. 79-91.

Wilson, D \& Mercier-Langevin, F 2013, 'Long hole blasting practices in a narrow vein deposit - experience from Agnico Eagle's Lapa mine', Proceedings of the 23rd World Mining Congress and Expo, Canadian institute of Mining, Metallurgy and Petroleum, Montreal. 